\title{
Effect of vaccination on the apparent prevalence of bovine brucellosis in the state of Tocantins, Brazil
}

\section{Efeito da vacinação na prevalência aparente da brucelose bovina no estado de Tocantins, Brasil}

\begin{abstract}
Fabiano Benitez Vendrame1; Regina Gonçalves Barbosa2; Fernando Ferreira ${ }^{3}$; Marcos Amaku4; Ricardo Augusto Dias4; José Henrique Hildebrand Grisi-Filho5; Marcos Heinemann Bryan ${ }^{4}$; Vitor Salvador Picão Gonçalves ${ }^{6}$; Oswaldo Santos Baquero5; José Soares Ferreira Neto ${ }^{3 *}$
\end{abstract}

\section{Highlights}

Bovine Brucellosis prevalence of infected herds and animals in the state of Tocantins.

Risk factors for Bovine Brucellosis in the state of Tocantins.

Brucellosis vaccination in the state of Tocantins reduced the prevalence.

\begin{abstract}
A cross-sectional study on the epidemiological situation of bovine brucellosis was carried out in the state of Tocantins to evaluate the effectiveness of its vaccination program. The state was divided into five regions, and a predetermined number of farms was randomly selected in each one. Females aged 24 months or older were randomly selected in each farm and diagnosed with brucellosis by serial serology (AAT and 2-ME). A total of 6,846 animals from 756 farms were examined. The prevalence of seropositive herds in the state was $6.42 \%$ [CI95\%: 4.76-8.62], and the prevalence of seropositive animals was $2.21 \%$ [CI95\%: $1.05-4.01$ ]. The prevalence of seropositive herds was homogeneously distributed among regions. The 2002/2003 study estimated the prevalence of seropositive herds in the state to be $21.22 \%$ [CI95\%: 19.33-23.11]. In conclusion, the vaccination program implemented in Tocantins, reaching vaccination coverage above $70 \%$ as of 2010, significantly reduced the prevalence of seropositive herds. Thus, continuing the vaccination

1 Veterinary, Agência de Defesa Sanitária Agrosilvopastoril do Estado de Rondônia, IDARON, Porto Velho, RO, Brazil. Doctoral Student of the Experimental and Applied Epidemiology to Zoonoses Program, Faculdade de Medicina Veterinária e Zootecnia, Universidade de São Paulo, FMVZ, USP, São Paulo, SP, Brazil. E-mail: fabianobvvet@gmail.com

2 Veterinary, Agência de Defesa Agropecuária do Estado do Tocantins, ADAPEC, Palmas, TO, Brazil. E-mail: r.g.barbosa@hotmail.com

${ }^{3}$ Full Professor, FMVZ, USP, São Paulo, SP, Brazil. E-mail: fferreir@usp.br; jsoares@usp.br

${ }^{4}$ Associate Professor, FMVZ, USP, São Paulo, SP, Brazil. E-mail: amaku@usp.br, ricardodias@usp.br; marcosbryan@ usp.br

${ }^{5}$ Assistant Professor, DVM, FMVZ, USP, São Paulo, SP, Brazil. E-mail: jgrisi@usp.br; baquero@usp.br

${ }^{6}$ Associate Professor, Faculdade de Agronomia e Medicina Veterinária, Universidade de Brasília, FAV, UNB, Brasília, DF, Brazil. E-mail: vitorspg@unb.br

* Author for correspondence
\end{abstract}

Received: Sept. 04, 2020 - Approved: Apr. 22, 2021 
program in the state is recommended, preferably increasing the quality of the processes involved, from commercialization to inoculation in animals, since immunization remains the most effective means to reduce the prevalence of brucellosis. In addition, animal replacement remains a major risk factor for bovine brucellosis in Tocantins since 20022003; therefore, the state must implement a strong health education program explaining to farmers the importance of testing animals for brucellosis before introducing them into their herds.

Key words: Infectious abortion. Zoonosis. Risk factors. S19. RB51.

\section{Resumo}

Foi realizado um estudo seccional sobre a situação epidemiológica da brucelose bovina no estado de Tocantins com o objetivo de avaliar a eficácia do programa de vacinação implementado. $O$ estado foi dividido em cinco regiões e em cada uma delas foi aleatoriamente amostrado um número pré-estabelecido de propriedades. Dentro de cada propriedade, fêmeas com idade igual ou superior a 24 meses foram aleatoriamente selecionadas e submetidas à sorologia em série para o diagnóstico da brucelose (AAT e 2-Mercaptoetanol). Ao todo foram examinados 6.846 animais oriundos de 756 propriedades. A prevalência aparente de focos no estado foi de 6,42\% [IC95\%: 4,76-8,62] e a de animais 2,21\% [IC95\%: 1,05-4,01]. A prevalência aparente de focos apresentou-se homogeneamente distribuída entre as cinco regiões. Como o estudo realizado em 2002/2003 estimou a prevalência aparente de focos no estado em 21,22\% [IC95\%: 19,33-23,11], conclui-se que o programa de vacinação implementado pelo Tocantins, atingindo coberturas vacinais acima de $70 \%$ a partir de 2010 , reduziu a prevalência de maneira importante. Assim, recomendase que o estado continue seu programa de vacinação, dando grande ênfase para a qualidade dos procedimentos, desde a comercialização do insumo até a inoculação nos animais, pois a imunização ainda é a maneira mais racional de se reduzir a prevalência da brucelose bovina no seu território. Adicionalmente, o estado deve implementar uma forte ação de educação sanitária para que os produtores passem a testar os animais para brucelose antes de introduzi-los nos seus rebanhos, pois verificou-se que a reposição de animais permanece associada à condição de foco da brucelose bovina desde 2002/2003.

Palavras-chave: Aborto infeccioso. Zoonose. Fatores de risco. S19. RB51.

\section{Introduction}

The state of Tocantins (TO) was formed on October 5, 1988, on the same day the Brazilian constitution came into force, and is thus the newest state in the federation. It is located in the northern region of Brazil and has a population of 1.6 million inhabitants distributed in 139 cities, covering an area of 278,000 km2 (Instituto Brasileiro de Geografia e Bioestatística [IBGE], 2019). Despite contributing only $0.5 \%$ of the Brazilian Gross
Domestic Product (GDP) (24th position), its cumulative growth has shown increasingly positive results in recent years, totaling BRL 28.5 billion in 2016, mostly due to sugar cane, soy, and trade. The primary sector accounts for $14 \%$ of Tocantins GDP, and $20 \%$ of this derives from raising livestock (Secretaria de Planejamento e Orçamento [SEPLAN], 2017).

Currently Tocantins is classified by the World Organization for Animal Health (OIE) as a free state with vaccination for foot-and- 
mouth disease, with no outbreaks since 1997 (Agência de Defesa Agropecuária do Estado de Tocantins [ADAPEC], 2021). This increased the economic value of the beef and dairy produced in the state and increased beef exports to $20 \%$ of total state exports (Secretaria da Agricultura, Pecuária e Aquicultura do Estado de Tocantins [SEAGRO], 2021). The herd is currently estimated at about 8.8 million head of cattle, and approximately 52,000 tons of meat are exported annually, corresponding to USD 162 million (SEAGRO, 2016). Considering the increasing health demands of the international consumer market and aiming to improve the health standards of the herds, the Official Veterinary Service (OVS) has been working to prevent exotic diseases and to control and eradicate important endemic diseases. One endemic disease that should be focused by the OVS is brucellosis, which, besides being a zoonosis, considerably decreases the productivity of beef and dairy production chains (Paulin \& Ferreira, 2003).

In cattle, brucellosis is mainly caused by Brucella abortus, but the animals are also susceptible to Brucella suis and Brucella melitensis when in close contact with infected pigs, goats and sheep, which are their natural hosts (Acha \& Szyfres, 2001). Brucella melitensis was not reported in Brazil (Minharro et al., 2013).

The most important symptoms of the disease in cattle are the occurrence of abortions in the final trimester of pregnancy and the birth of weak calves (Thoen, Enright, \& Cheville, 1993; Acha \& Szyfres, 2001) which trigger increased calving interval, calf death, low reproductive rates, decreased milk and meat production, and consequently, significant economic losses (Paulin \& Ferreira, 2002).
In addition to economic losses, bovine brucellosis is a classic anthropozoonosis that affects humans mainly through direct contact with infected animals and consumption of milk or other dairy products produced without heat treatment (Paulin \& Ferreira, 2002). The symptoms in humans are nonspecific; therefore, the prevalence of human infection is consistently underestimated. Data on disease quantification in humansare rare. Baruffa(1978) reported that, in Rio Grande do Sul, brucellosis was more frequent in rural inhabitants and affected more men than women. The consumption of unpasteurized cheese would be the most important source of infection. In 1988, Homem, Heinemann, Higa and Ferreira Neto (2016) reported that 21\% [13-31] of the families in the city of Uruará, Pará, had at least one brucellosis-positive member with a mean of $23 \%$ seropositivity. Freitas, Santos, Almeida \& Alexandrino (2020), studying patient records from 2010 to 2016, reported 44 cases of human brucellosis in the Araguaína region, TO, associated with sex (male), rural residents, higher education level and contact with animal tissues and brucellosis vaccine.

Owing to the importance of this disease for the Brazilian beef and dairy production chains and for being a zoonosis, in 2001, the Ministry of Agriculture, Livestock and Supply (Ministério da Agricultura, Pecuária e Abastecimento - MAPA) implemented the National Program for Control and Eradication of Brucellosis and Tuberculosis. (PNCEBT) (Lage et al., 2006). At the same time, MAPA, together with state Official Veterinary Services (OVS) and the Collaborating Center on Animal Health of the School of Veterinary Medicineand Animal Science of the University of São Paulo (FMVZUSP), began to epidemiologically characterize the disease in all Brazilian federative units. 
To date, 18 federative units have conducted these studies (Alves et al., 2009; Almeida et al., 2016; Azevedo et al., 2009; Borba et al., 2013; Chate et al., 2009; Clementino et al., 2016; J. A. Dias et al., 2009a; R. A. Dias et al., 2009b; Gonçalves et al., 2009a,b; Klein-Gunnewiek et al., 2009; Marvulo et al., 2009; Negreiros et al., 2009; Ogata et al., 2009; Rocha et al., 2009; Sikusawa et al., 2009; V. G. S. O. Silva et al., 2009; Villar et al., 2009), representing $85 \%$ of the Brazilian cattle herd (see Figure 1).

Eight states (Minas Gerais, Rondônia, Mato Grosso, Mato Grosso do Sul, Espírito Santo, Rio Grande do Sul, and São Paulo) repeated the study to verify the effectiveness of their vaccination programs on the prevalence of bovine brucellosis (Barddal et al., 2016; R. A. Dias et al., 2016; Anzai et al., 2016; Inlamea et al., 2016; Leal et al., 2016; Oliveira et al., 2016; N. S. Silva et al., 2016). The study was also repeated in Santa Catarina (Baumgarten et al., 2016), but with the objective of verifying whether the prevalence remained very low at the levels reported by Sikusawa et al. (2009) in 2001. Of these states, only Minas Gerais, Rondônia, Mato Grosso, and Mato Grosso do Sul managed to decrease prevalence through effective vaccination programs (Ferreira Neto et al., 2016).

In 2002/2003, the state of Tocantins had an infected herd prevalence of $21.2 \%$ [19.3-23.1] and animal prevalence of $4.4 \%$ [3.6-5.3] (Ogata et al., 2009). Following these results, the implementation of a brucellosis vaccination program was recommended as the most effective mean to decrease prevalence, using S19 and RB51 (from 2007) vaccines. Figure 2 shows the vaccination coverage achieved by the state since 2004, highlighting that vaccination coverage reached $>70 \%$ after 2010. The objective of the present study was to verify whether the bovine brucellosis vaccination program implemented by the state of Tocantins resulted in decreased apparent prevalence of brucellosis. Risk factors associated with seropositive herds of bovine brucellosis in the state were also studied. 


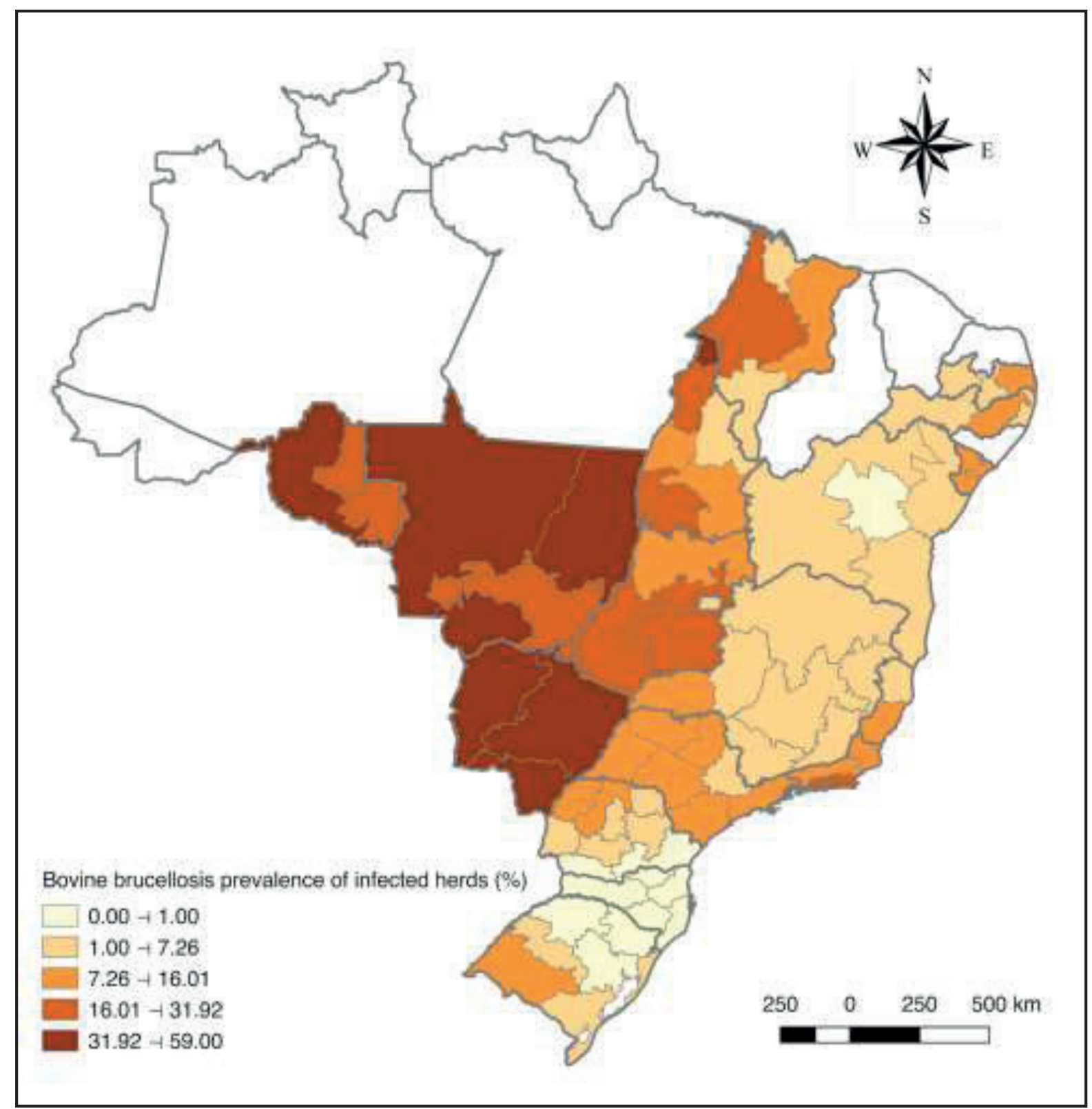

Figure 1. Prevalence of bovine brucellosis infected herds in Brazil according to the first MAPA standardized studies.

Source: Ferreira Neto et al. (2016). 


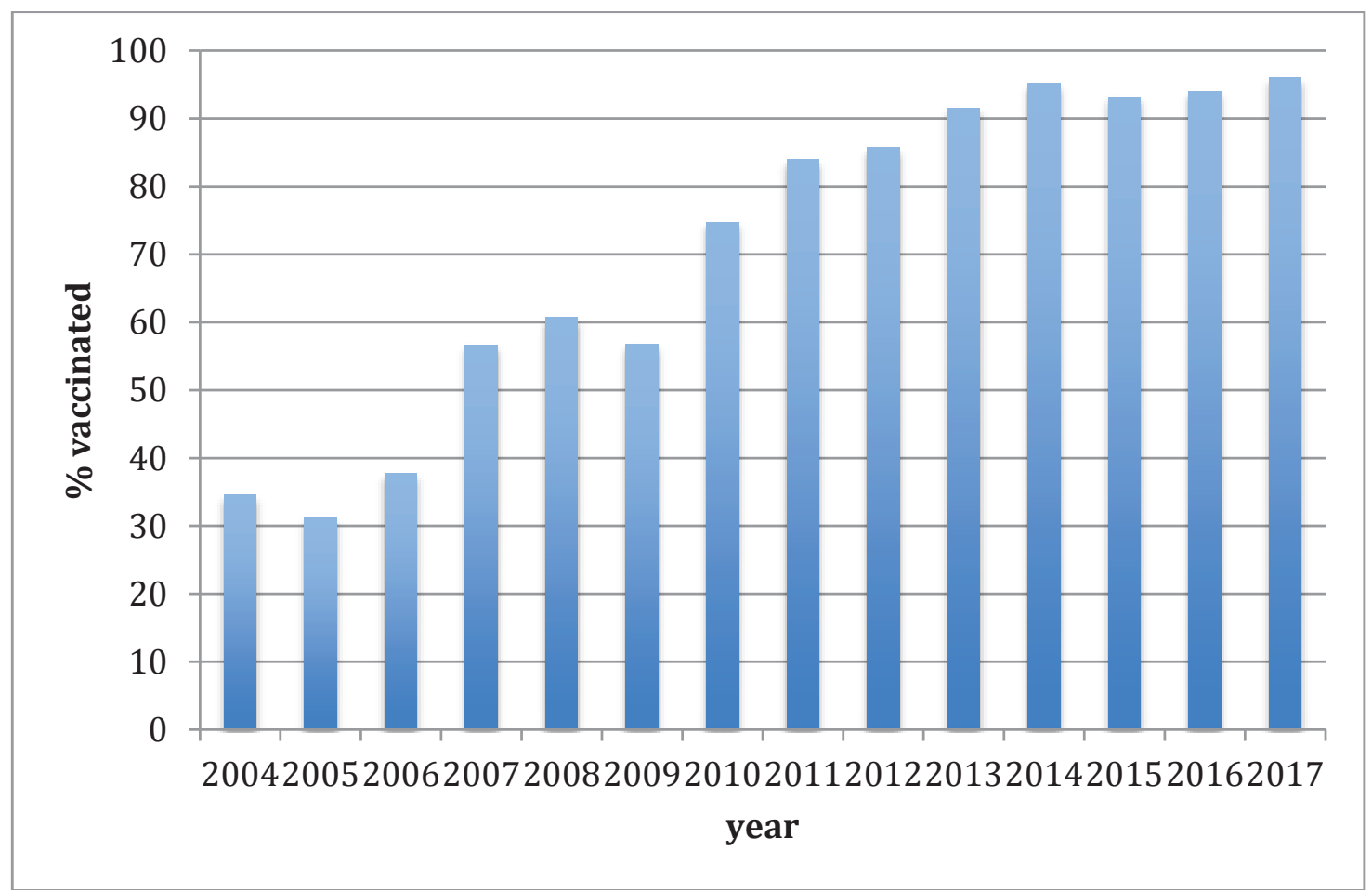

Figure 2. S19 vaccination coverage in the state of Tocantins from 2004 to 2017. Source: unpublished data from the Official Veterinary Service of the State of Tocantins (Agência de Defesa Agropecuária do estado de Tocantis - ADAPEC) and Ministério da Agricultura, Pecuária e Abastecimento [MAPA] (2020).

\section{Material and Methods}

This study was planned by technicians from MAPA, the Collaborating Center on Animal Health of the School of Veterinary Medicine and Animal Science of the University of São Paulo (FMVZ-USP), and from the OVS of the state of Tocantins (Agência de Defesa Agropecuária do estado de Tocantis - ADAPEC), the latter being responsible for fieldwork from October 2014 to August 2015. The state was divided into five regions based on difference in production systems, management practices, exploitation types, mean herd size, animal marketing systems, and animal health defense operational capacity (Figure 3). A predetermined number of farms with reproductive activity (primary sampling units) was randomly selected within each of these regions from the farm register maintained by ADAPEC. Then, a predetermined number of female cows aged 24 months or older (secondary sampling units) was randomly selected within each selected farm.

In the farms that contained more than one herd, the most economically important herd was selected for analysis of animals raised under the same management practices, i.e., under the same risks of exposure to infection. If for any reason the selected farm could not be visited, another was selected. The number of farms selected by region was 
estimated by the simple random sampling formula (Thrusfield, 2007). The parameters used to meet the operational capacity of the state were: 0.95 confidence level, estimated prevalence of 0.20 , and error of 0.05 .

The sampling plan for the secondary units aimed at estimating the minimum number of animals required in each farm to classify them as infected or brucellosis-free, using the concept of aggregate sensitivity and specificity (Dohoo, Martin, \& Stryhn, 2012). The sensitivity and specificity of the test protocol used for calculations were 0.85 and 0.99, respectively (Rose Bengal test: 96.2\% sensitivityand 97,1\% specificity (Davies, 1971); 2-mercaptoetanol test: $88.4 \%$ sensitivity and $91.5 \%$ specificity (Gall \& Nielsen, 2004)), and 0.20 for estimated prevalence. The online Epitools software (https://epitools.ausvet. com.au/herdplusthree) was used to determine a sample size that would allow herd sensitivity and specificity values $\geq 86 \%$ and $95 \%$, respectively. Thus, 10 animals were sampled from farms with up to 99 females aged 24 months or over, and 15 animals were sampled from farms with 100 or more females aged 24 months or over. Females in the peripartum period, i.e., approximately 15 days before and after calving, were excluded from the study.

Blood samples were collected from all selectedanimals ina previouslyidentified blood collection tube by puncture of the jugular vein using a sterile disposable needle. The sera were frozen at $-20^{\circ} \mathrm{C}$ in polypropylene microtubes for posterior testing. Serodiagnosis consisted of screening with the buffered acidified antigen test and confirmatory 2-mercaptoethanol test following the protocols described by Lage et al. (2006). A farm was considered to be positive when at least one positive animal was detected.

The sampling design allowed us to determine the apparent prevalence of bovine brucellosis infected herds and adult females ( $\geq 24$ months) in the state and also regionally. Prevalence and respective confidence intervals were calculated as recommended by Dean et al. (1996). Estimates of outbreak and animal prevalence in the state and animal prevalence in the regions were weighted as recommended by Dohoo et al. (2012). The weight of each farm used to determine the apparent prevalence of infected herds in the state was given by:

$$
P_{1}=\frac{\text { Farms with reproductive activity in the region }}{\text { Farms with reproductive activity sampled in the region }}
$$

The weight of each animal used to calculate animal prevalence in the state was given by:

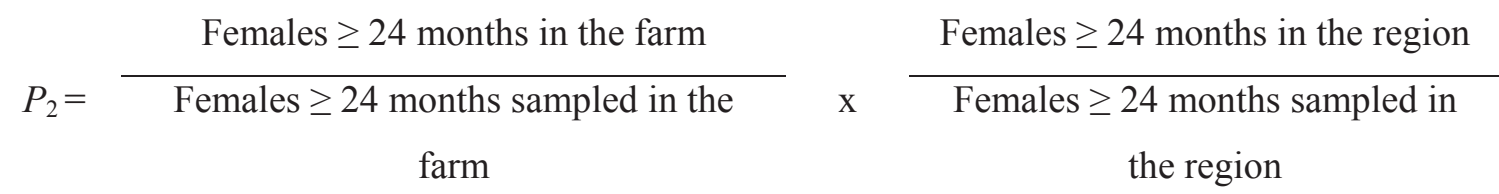


In the equation above, the first term refers to the weight of each animal used to calculate the apparent prevalence of animals in each region. SPSS version 9.0 was used to estimate the prevalence with confidence intervals (95\%). An epidemiological questionnaire was also filled in at each sampled farm to obtain information on the types of exploitation and management practices implemented.

The variables analyzed were: farm typology (beef, dairy, and mixed), type of raising (confined, semi-confined, and extensive), use of artificial insemination, predominant breeds, number of animals, presence of other domestic and wild species, occurrence of abortion in the last 2 years, destination of the placenta and aborted fetuses, animal purchase, vaccination against bovine brucellosis, pastures shared between farms, occurrence of flooding in pastures, presence of calving facilities, presence of area where livestock remains concentrated and veterinary assistance. The variables were organized in an increasing risk scale. When necessary, they were recategorized. The lowest risk category was considered to be the basis for comparison with the others. Quantitative variables were categorized into percentiles. Exploratory (univariate) analysis was used to select the significant variables $(p<0.20)$ for the $x 2$ (chi-square) or Fisher's exact test, and subsequently, logistic regression, as recommended by Hosmer and Lemeshow (2000). SPSS version 9.0 was used for the calculations. Field and laboratory information was entered into a database used for epidemiological analyses at the FMVZ-USP Laboratory of Epidemiology and Biostatistics (LEB).

\section{Results and Discussion}

Figure 3 shows the state of Tocantins divided into the five study regions. Table 1 shows the census and sampling data for the state of Tocantins. Table 2 shows the prevalence of bovine brucellosis seropositive herds and positive animals by region and state. Table 3 shows the prevalence of bovine brucellosis seropositive herds stratified by the farm typology.

The prevalence of bovine brucellosis seropositive herds in the state was $6.42 \%$ [4.76-8.62], with no differences among regions (Table 2). The same results were observed for animal prevalence, except for the comparison between regions 1 and 5 (Table 2). Although the prevalence of seropositive herds tended to be higher in beef and mixed farms compared with dairy farms, no significant differences were observed among the three types (Table 3). However, it is important to note that the confidence intervals presented in Table 3 are higher owing to the small sample size, e.g., in region 3, only one dairy farm was sampled, resulting in a confidence interval of $0-77.6 \%$. 

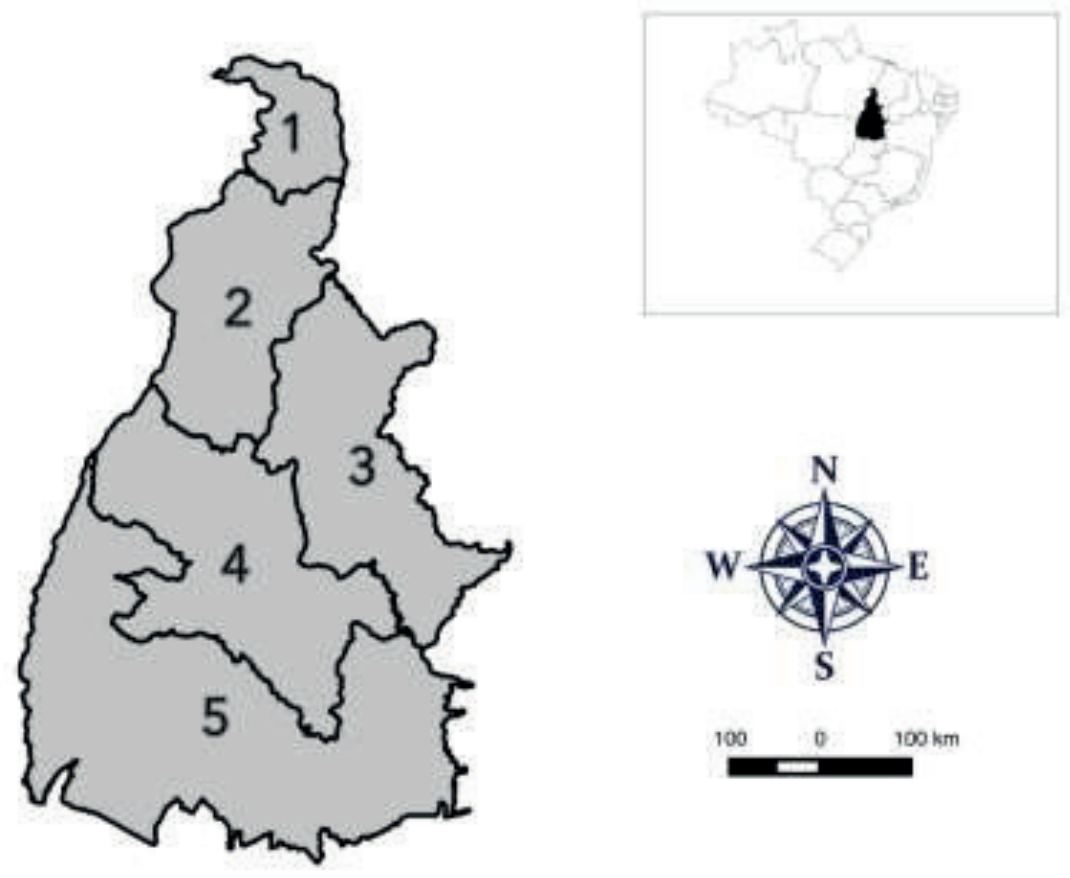

Figure 3. Map of the state of Tocantins divided into the five study regions: 1) Bico do Papagaio, 2) Araguaína, 3) Jalapão, 4) Central, and 5) South. Inset map shows the location of Tocantins in Brazil. Source: LEB/FMVZ-USP.

\section{Table 1}

Registration data from ADAPEC and sampling data for bovine brucellosis in the state of Tocantins, Brazil, 2014-2015

\begin{tabular}{clcccc}
$\begin{array}{c}\text { region } \\
\text { number }\end{array}$ & region name & $\begin{array}{c}\text { number of herds } \\
\text { with reproductive } \\
\text { activity }\end{array}$ & $\begin{array}{c}\text { number of } \\
\text { females aged } \geq \\
24 \text { months }\end{array}$ & $\begin{array}{c}\text { number of } \\
\text { sampled } \\
\text { herds }\end{array}$ & $\begin{array}{c}\text { number of females } \\
\text { aged } \geq 24 \text { months } \\
\text { sampled }\end{array}$ \\
\hline 1 & Bico do Papagaio & 6685 & 289211 & 151 & 1328 \\
2 & Araguaína & 13225 & 839205 & 151 & 1351 \\
3 & Jalapão & 5725 & 227460 & 151 & 1326 \\
4 & Central & 13128 & 845629 & 153 & 1399 \\
5 & Sul & 15256 & 1276413 & 150 & 1442 \\
& $\quad$ Total & 54019 & 3477918 & 756 & 6846 \\
\hline
\end{tabular}

Source: Official Veterinary Service of the State of Tocantins (Agência de Defesa Agropecuária do estado de Tocantis ADAPEC). 
Table 2

Prevalence of bovine brucellosis infected herds and positive animals with respective confidence intervals (CI) by regions of the state of Tocantins. Brazil, 2014-2015

\begin{tabular}{ccccccccc} 
& \multicolumn{3}{c}{ animals } \\
\cline { 2 - 8 } region & tested & positive & $\begin{array}{c}\text { prevalence } \\
(\%)\end{array}$ & $\begin{array}{c}\mathrm{Cl} 95 \% \\
(\%)\end{array}$ & tested & positive & $\begin{array}{c}\text { prevalence } \\
(\%)\end{array}$ & $\begin{array}{c}\mathrm{Cl} 95 \% \\
(\%)\end{array}$ \\
\hline 1 & 1328 & 10 & 0.26 & $0.06-0.70$ & 151 & 9 & 5.96 & $3.11-11.13$ \\
2 & 1351 & 12 & 1.79 & $0.17-6.80$ & 151 & 9 & 5.96 & $3.11-11.13$ \\
3 & 1326 & 6 & 0.47 & $0.06-1.64$ & 151 & 5 & 3.31 & $1.37-8.78$ \\
4 & 1399 & 13 & 1.42 & $0.30-4.05$ & 153 & 9 & 5.88 & $3.07-10.99$ \\
5 & 1442 & 23 & 3.77 & $1.44-7.91$ & 150 & 13 & 8.67 & $5.07-14.43$ \\
Total & 4005 & 28 & 2.21 & $1.05-4.01$ & 453 & 23 & 6.42 & $4.76-8.62$ \\
\hline
\end{tabular}

Table 3

Prevalence of bovine brucellosis infected herds with respective confidence intervals, stratified by farm typology in the regions of the state of Tocantins, Brazil, 2014-2015

\begin{tabular}{|c|c|c|c|c|c|c|c|c|c|}
\hline \multirow[b]{2}{*}{ region } & \multicolumn{3}{|c|}{ beef herds } & \multicolumn{3}{|c|}{ dairy herds } & \multicolumn{3}{|c|}{ mixed herds } \\
\hline & $\begin{array}{l}\text { positive } \\
\text { /tested }\end{array}$ & $\begin{array}{l}\text { preva- } \\
\text { lence (\%) }\end{array}$ & $\begin{array}{c}\mathrm{Cl} 95 \% \\
(\%)\end{array}$ & $\begin{array}{l}\text { positive } \\
\text { /tested }\end{array}$ & $\begin{array}{l}\text { preva- } \\
\text { lence (\%) }\end{array}$ & $\begin{array}{c}\mathrm{Cl} 95 \% \\
(\%)\end{array}$ & $\begin{array}{l}\text { positive } \\
\text { /tested }\end{array}$ & $\begin{array}{l}\text { preva- } \\
\text { lence (\%) }\end{array}$ & $\begin{array}{c}\mathrm{Cl} 95 \% \\
(\%)\end{array}$ \\
\hline 1 & $5 / 56$ & 8.93 & $3.87-19.3$ & $1 / 30$ & 3.33 & $0.59-16.7$ & $3 / 64$ & 4.69 & $1.61-12.9$ \\
\hline 2 & $3 / 63$ & 4.76 & $1.63-13.1$ & $2 / 54$ & 3.70 & $1.02-12.5$ & $4 / 34$ & 11.8 & $4.67-26.6$ \\
\hline 3 & $4 / 123$ & 3.25 & $1.27-8.06$ & $0 / 1^{*}$ & 0 & $0-77.6$ & $1 / 27$ & 3.70 & $0.66-18.3$ \\
\hline 4 & 9/104 & 8.57 & $4.57-15.5$ & $0 / 7^{*}$ & 0 & $0-31.2$ & $0 / 42^{*}$ & 0 & $0-6.73$ \\
\hline 5 & $12 / 123$ & 9.76 & $5.67-16.3$ & $0 / 6^{*}$ & 0 & $0-34.8$ & $1 / 21$ & 4.76 & $0.85-22.7$ \\
\hline
\end{tabular}

* Confidence Interval (Cl) calculated by the $\beta$ distribution and Monte Carlo simulation.

Compared with the first brucellosis study conducted in Tocantins between February 2002 and August 2003, a reduction in the prevalence of bovine brucellosis seropositive herds from $21.22 \%$ [19.3323.11] (Ogata et al., 2009) to $6.42 \%$ [4.768.62] was observed in the present study (Table 2). Considering point estimates of animal prevalence, there was also a reduction from 4.43\% [3.57-5.29] (Ogata et al., 2009) to $2.21 \%$ [1.05-4.01] in the present study, but the difference was not significant. This reduction in infected farms prevalence was a consequence of the effective brucellosis vaccination program implemented by the state, which has achieved a vaccine coverage $>70 \%$ since 2010 (Figure 1), corroborating the results from a mathematical model of the effects of vaccination on brucellosis prevalence (Amaku, Dias, Ferreira, \& Ferreira, 2009). Thus, Tocantins managed to reduce the prevalence of brucellosis seropositive herds through the implementation of effective vaccination programs, similar to Mato Grosso, 
Rondônia, Mato Grosso do Sul, and Minas Gerais (Barddal et al., 2016; Ferreira Neto et al., 2016; Inlamea et al., 2016; Leal et al., 2016; Oliveira et al., 2016).

The five regions of the state differed from those used in the 2002/2003 study (Ogata et al., 2009), and only Bico do Papagaio and Araguaína remained, as shown in Figure 4. Comparing the regions between the two studies, showed that seropositive herds prevalence reduced in both Bico do Papagaio and Araguaína. Although the point values of animal prevalence were also reduced in these two regions, only in Bico do Papagaio was the difference significant between the 2002/2003 and 2014/2015 studies. The prevalence of seropositive herds in Bico do Papagaio reduced from 37.63 [32.08-43.43] in $2002 / 2003$ to 5.96 [3.11-11.13] in the present study, and the prevalence of animals reduced from 8.54 [5.89-11.18] to 0.26 [0.06-0.70]. In Araguaína, the prevalence of seropositive herds reduced from 29.26 [24.26-34.66] in $2002 / 2003$ to 5.96 [3.11-11.13] in the present study, and the prevalence of animals reduced from 6.40 [3.92-8.89] to 1.79 [0.17-6.80]. Using a different methodology than that adopted in the present study, Baptista, Haddad, Almeida and Nardi (2012) reported prevalence of infected herds and animals of $43.5 \%$ and $6.2 \%$, respectively, for the Araguaína region in 2010.

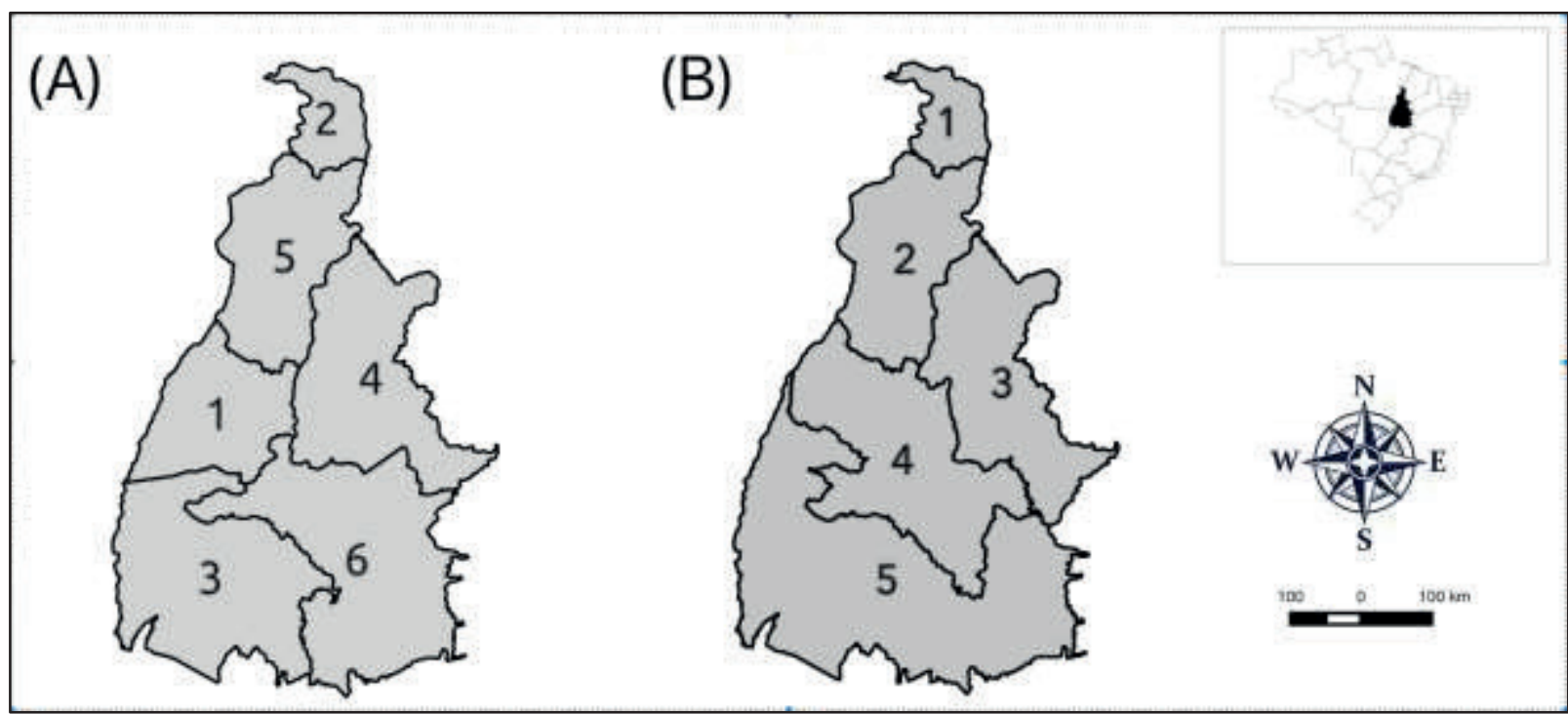

Figure 4. Regions of the state of Tocantins considered in studies conducted in 2002/2003 (A) and $2014 / 2015$ (B) on the epidemiology of bovine brucellosis.

Source: LEB/FMVZ-USP.

Considering the most recent results regarding the prevalence of bovine brucellosis seropositive herds in the federative units that conducted studies standardized by MAPA and the Collaborating Center on Animal Health of FMVZ-USP, Tocantins exhibited the same seropositive herds prevalence as Paraíba, Pernambuco, Espírito Santo, Rio Grande do 
Sul, Bahia, Federal District, and Paraná; a lower seropositive herds prevalence than Mato Grosso do Sul, Mato Grosso, Rondônia, São Paulo, Goiás, Rio de Janeiro, Sergipe, and Maranhão; and a higher seropositive herds prevalence than Santa Catarina and Minas Gerais (Almeida et al., 2016; Alves et al., 2009; Anzai et al., 2016; Barddal et al., 2016; Baumgarten et al., 2016; Borba et al., 2013; Clementino et al., 2016; J. A. Dias et al., 2009a; R. A. Dias et al., 2016; Gonçalves et al., 2009ab; Inlamea et al., 2016; Klein-Gunnewiek et al., 2009; Leal et al., 2016; Ogata et al., 2009;
Oliveira et al., 2016; Rocha et al., 2009; V. G. S. O. Silva et al., 2009; N. S. Silva et al., 2016). MAPA recently instituted a matrix to compare federal units regarding actions to combat bovine brucellosis, in which the prevalence of seropositive herds is an important element (MAPA, 2017).

The final model of multivariate logistic regression (Table 4) showed that bovine brucellosis seropositive herds were associated with farms that contained $\geq 45$ cows and had purchased breeding animals at fairs and auctions.

\section{Table 4}

Final logistic regression model for bovine brucellosis in the state of Tocantins. Brazil, 2014-2015

\begin{tabular}{cccc} 
Variable & Odds Ratio & Cl 95\% & p Value \\
\hline herd size $\geq 45$ females aged $\geq 24$ months (3rd quartile) & 2.5 & $1.3-4.8$ & 0.008 \\
purchase of breeding animals at fairs / auctions & 4.8 & $1.2-19.6$ & 0.029
\end{tabular}

The association between brucellosis and herd size has been reported previously (Kellar, Marra, \& Martin, 1976; Salman \& Meyer, 1984). Some of the characteristics found in larger herds facilitate brucellosis transmission, especially the increased need for animal replacement (Crawford, Huber, \& Adams, 1990; Christie, 1969), indirectly suggesting that animal replacement, which is more frequent in larger herds, is the true cause of increased disease vulnerability. In Brazil, the same association was reported in Mato Grosso (Negreiros et al., 2009; Barddal et al., 2016), Mato Grosso do Sul (Chate et al., 2009; Leal et al., 2016), Rio de Janeiro (Klein-Gunnewiek et al., 2009), Sergipe (V. G. S. O. Silva et al., 2009), São Paulo (Dias et al., 2009a; R. A. Dias et al., 2016), Espírito Santo (Anzai et al., 2016), Minas Gerais (Oliveira et al., 2016), Pernambuco (Almeida et al., 2016), Rondônia (Inlamea et al., 2016), Rio Grande do Sul (N. S. Silva et al., 2016), Santa Catarina (Baumgarten et al., 2016), Maranhão (Borba et al., 2013), and also in the first study on bovine brucellosis in Tocantins in 2002/2003 (Ogata et al., 2009). These results indicate that herd size is directly proportional to the occurrence, maintenance, spread, and the difficulties involved in eradicating bovine brucellosis (Christie, 1969). The introduction of breeding animals purchased from fairs and auctions increases the risk of introducing brucellosis into the herd, similar to the abovementioned variable. 


\section{Conclusion}

The current prevalence can still be reduced if the state maintains high vaccine coverage, preferably increasing the quality of the processes involved, from commercialization to inoculation in animals. In addition, the use of RB51 should be promoted to accelerate the shift from susceptible to resistant populations (Souza et al., 2016), which would result in a positive effect in reducing prevalence. The state must implement a strong and effective health education program to explain to farmers the importance of testing animals for brucellosis before introducing them into their herds.

\section{Acknowledgements}

The authors thank the financial support of the MAPA, ADAPEC, CAPES - Finance Code 001, and Fapesp (Public Policy Process 2017/50190-1).

\section{References}

Acha, P. N., \& Szyfres, B. (2001). Brucelosis. In Zoonosis: enfermedades transmissibles comunes al hombre y a los animales. Publicación Científica y Técnica, 580). Washington: Organización Panamericana de la Salud.

Agência de Defesa Agropecuária do Estado de Tocantins (2021). Programa estadual de erradicação da febre aftosa. Recuperado de https://adapec.to.gov.br/animal/sani dade-animal/programa-estadual-de-erra dicacao- da-febre-aftosa---peefa

Almeida, E. C., Freitas, A. A., Pontual, K. A Q., Souza, M. M. A., Amaku, M., Dias, R.
A.,... Silva, J. C. R. (2016). Prevalence and associated risk factors for bovine brucellosis in the state of Pernambuco, Brazil. Semina: Ciências Agrárias, 37(5), 3413-3424. doi: 10.5433/1679-039.2016 v37n5Supl2p3413

Alves, A. J. S., Gonçalves, V. P. S., Figueiredo, V. C. F., Lôbo, J. R., Bahiense, L., Amaku, M.,... Dias, R. A. (2009). Situação epidemiológica da brucelose bovina no estado da Bahia. Arquivo Brasileiro de Medicina Veterinária e Zootecnia, 61(Supl. 1), 6-13. doi: 10.15 90/S0102-09352009000700002

Amaku, M., Dias, R. A., Ferreira, J. S. Neto, \& Ferreira, F. (2009). Modelagem matemática do controle de brucelose bovina por vacinação. Arquivo Brasileiro de Medicina Veterinária e Zootecnia, 61(Supl. 1), 135-141. doi: 10.1590/S010209352009000700017

Anzai, E. K., Costa, D., Said, A. L. P. R., GrisiFilho, J. H. H.., Amaku, M., Dias, R. A.,... Ferreira Neto, J. S. (2016). An update on the epidemiological situation of bovine brucellosis in the state of Espírito Santo, Brazil. Semina: Ciências Agrárias, 37(5), 3437-3448. doi: 10.5433/ 1679-0359.2016v37n5Supl2p3437

Azevedo, S. S., Ferreira Neto, J. S., Dias, R. A., Ferreira, F., Amaku, M., Figueiredo, V. C. F.,... Vasconcellos, S. A. (2009). Situação epidemiológica da brucelose bovina no estado do Espírito Santo. Arquivo Brasileiro de Medicina Veterinária e Zootecnia, 61(Supl. 1), 19-26. doi: 10.15 90/S0102-09352009000700004

Baptista, F., Leite, R. C., Haddad, J. P. A., Almeida, K. S., \& Nardi, C. P. P. (2012). Prevalende and risk factors for brucellosis in Tocantins and Brazilian national program 
to fight this disease. Revista de Patologia Tropical, 41(3), 285-294. doi: 10.5216/rpt. v41i3.20755

Barddal, J. E. I., Santos, J. C. Q., Lopes, I. F. Ferreira Neto, J. S., Ferreira, F., Amaku, M.,... Aguiar, D. M. (2016). Effect of vaccination in lowering the prevalence of bovine brucellosis in the state of Mato Grosso, Brazil. Semina: Ciências Agrárias, 37(5), 3479-3492. doi: 10.5433 /1679-0359.2016v37n5Supl2p3479

Baruffa, G. (1978). Prevalência sorológica da brucelose na zona sul do Rio Grande do Sul (Brasil). Revista Instituto de Medicina Tropical, 20(2), 71-75. Recuperado de http://www.imt.usp.br/wp-content/uploa ds/revista/vol20/71-75.pdf

Baumgarten, K. D., Veloso, F. P., Grisi, J. H. H., F., Ferreira, F., Amaku, M., Dias, R. A.,... Ferreira Neto, J. S. (2016). Prevalence and risk factors for bovine brucellosis in Santa Catarina state, Brazil. Semina: Ciências Agrárias, 37(5), 3425-3436. doi: 10.5433/ 1679-0359.2016v37n5Supl2p3425

Borba, M. R., Stevenson, M. A., Gonçalves, V. S. P., Ferreira Neto, J. S., Ferreira, F., Amaku, M.,... Dias, R. A. (2013). Prevalence and risk-mapping of bovine brucellosis in Maranhão State, Brazil. Preventive Veterinary Medicine, 110(2), 169-176. doi: 10.1016/j.prevetmed.2012.11.013

Chate, S. C., Dias, R. A., Amaku, M., Ferreira, F., Moraes, G. M., Costa, A. A.,... Ferreira Neto, J. S. (2009). Situação epidemiológica da brucelose bovina no estado do Mato Grosso do Sul. Arquivo Brasileiro de Medicina Veterinária e Zootecnia, 61, (Supl. 1), 46-55. doi: 10.1590/S0102-09 352009000700007
Christie, T. E. (1969). Eradication of brucellosis in Northern Ireland: field problems and experiences. Veterinary Record, 85(10), 268-269. doi: 10.1136/vr.85.10.268

Clementino, I. J., Dias, R. A., Amaku, M., Ferreira, F., Telles, E. O., Heinemann, M. B.,... Azevedo, S. S. (2016). Epidemiological situation of bovine brucellosis in the state of Paraiba, Brazil. Semina: Ciências Agrárias, 37(5), 3403-3412. doi: 10.5433/ 1679-0359.2016v37n5Supl2p3403

Crawford, R. P., Huber, J. D., \& Adams, B. S. (1990). Epidemiology and surveillance. In K. Nielsen, \& J. R. Duncan (Eds.). Animal brucellosis (pp. 131-151). Boca Raton: CRC Press.

Davies, G. (1971). The Rose Bengal Test. The Veterinary Record, 88(17), 447-449.

Dean, A. G., Dean, J. A., Coulombier, D., Brendel, K. A., Smith, D. C., Burton, A. H., Arner, T. G. (1996). Epi Info, version 6: a word processing, database, and statistics program for public health on IBM-compatible microcomputers. Atlanta: Centers for Disease Control and Prevention.

Dias, J. A., Müller, E. E., Dias, R. A., Freitas, J. C., Amaku, M., Ferreira, F., Ferreira Neto, J. S. (2009a). Situação epidemiológica da brucelose bovina no estado do Paraná. Arquivo Brasileiro de Medicina Veterinária e Zootecnia, 61(Supl. 1), 66-76. doi: 10. 1590/S0102-09352009000700009

Dias, R. A., Belchior, A. P. C., Ferreira, R. S., Gonçalves, R. C., Aguiar, R. S. C. B., Sousa, P. R.,... Ferreira Neto, J. S.. (2016). Controlling bovine brucellosis in the state of São Paulo, Brazil: results of ten years of vaccination program. Semina: 
Ciências Agrárias, 37(5), 3505-3518. doi: 10.5433/1679-0359.2016v37n5Supl2 p3505

Dias, R. A., Gonçalves, V. S. P., Figueiredo, V. C. F., Lôbo, J. R., Lima, Z. M. B., Paulin, L. M. S.,... Ferreira, F. (2009b). Situação epidemiológica da brucelose bovina no estado de São Paulo. Arquivo Brasileiro de Medicina Veterinária e Zootecnia, 61(Supl. 1), 118-125. doi: 10.1590/S010209352009000700015

Dohoo, I., Martin, W., \& Stryhn, H. (2012). Methods in epidemiologic research. Prince Edward Island, Canada: VER Inc.

Ferreira Neto, J. S., Silveira, G. B., Rosa, B. M. Gonçalves, V. S. P., Grisi-Filho, J. H. H., Amaku, M.,... Lage, A. P. (2016). Analysis of 15 years of the national program for the control and eradication of animal brucellosis and tuberculosis, Brazil. Semina: Ciências Agrárias, 37(5), 33853402. doi: 10.5433/1679-0359.2016v37 n5Supl2p3385

Freitas, N. S., Santos, H. D., Almeida, K. S., \& Alexandrino, B. (2020). Perfil epidemiológico dos casos de brucelose humana notificados no município de Araguaína/TO, no período de 2010 a 2016. Revista Cereus, 12(1), 117-136. doi: $10.18605 / 2175-7275$

Gall, D., \& Nielsen, K. (2004). Serological diagnosis of bovine brucellosis: a review of test performance and cost comparison. Scientific and Technical Review of the Office International des Epizooties, 23(3), 989-1002. doi: 10.20506/rst.23.3.1545

Gonçalves, V. S. P., Delphino, M. K. V. C., Dias, R. A., Ferreira, F., Amaku, M., Ferreira Neto, J. S.,... Lobo, J. R. (2009a). Situação epidemiológica da brucelose bovina no estado de Minas Gerais. Arquivo Brasileiro de Medicina Veterinária e Zootecnia, 61(Supl. 1), 35-45, 2009a. doi: 10.1590/ s0102-0935200 9000700006

Gonçalves, V. S. P., Ribeiro, L. A., Caldas, R. A., Francisco, P. F. C., Dias, R. A., Ferreira, F.,... Borges, J. R. J. (2019b). Situação epidemiológica da brucelose bovina no Distrito Federal. Arquivo Brasileiro de Medicina Veterinária e Zootecnia, v.61, supl.1, 14-18. doi: 10.1590/S010209352009000700003

Homem, V. S. F., Heinemann, M. B., Higa, Z. M. M., \& Ferreira Neto, J. S. (2016). Bovine and human brucellosis in the TransAmazonian agricultural frontier, Uruará, Pará, Brazil. Semina: Ciências Agrárias, 37(5), 3803-3808. doi:10.5433/1679-03 59.2016v37n5Supl2p3803

Hosmer, D. W., \& Lemeshow, S. (2000). Applied logistic regression (2nd ed.). New York, NY: Wiley-Interscience.

Inlamea, O. F., Rocha, A. B., Ferreira, F., GrisiFilho, J. H. H.., Heinemann. M. B., Dias, R. A.,... Ferreira Neto, J. S.. (2016). Effect of vaccination in lowering bovine brucellosis in the state of Rondonia, Brazil. Semina: Ciências Agrárias, 37(5), 3493-3503. doi: 10.5433/1679-0359.2016v37n5Supl2 p3493

InstitutoBrasileiro de Geografia Bioestatística (2019). Cidades e Estados - Tocantins. Recuperado de https://www.ibge.gov.br/ cidades-e-estados/to.html

Kellar, J., Marra, R., \& Martin, W. (1976). Brucellosis in Ontario: a case control study. Canadian Journal of Comparative Medicine, 40(2), 119-128. Recuperado 
de https://www.ncbi.nlm.nih.gov/pmc/arti cles/PMC 1277534/?page=1

Klein-Gunnewiek, M. F. C., Amaku, M., Dias, R. A., Ferreira, F., Gitti, C. B., Pereira, L. A.,... Ferreira Neto, J. S.. (2009). Situação epidemiológica da brucelose bovina no estado do Rio de Janeiro. Arquivo Brasileiro de Medicina Veterinária e Zootecnia, 61(Supl. 1), 77-84. doi: 10.15 90/S0102-09352009000700010

Lage, A. P., Roxo, E., Muller, E. E., Poester, F. P., Cavalléro, J. C. M., Ferreira Neto, J. S.,... Gonçalves, V. S. P. (2006). Programa nacional de controle e erradicação da brucelose e da tuberculose (PNCEBT). Brasília: MAPA/SDA/DSA.

Leal, J. M., Fo., Bottene, I. F. N., Monteiro, L. A. R. C., Pellegrin, A. O., Gonçalves, V. S. P., Ferreira, F.,... Ferreira Neto, J. S.. (2016). Control of bovine brucellosis from 1998 to 2009 in the state of Mato Grosso do Sul, Brazil. Semina: Ciências Agrárias, 37(5), 3467-3478. doi: 10.5433/1679-0359.2016v37n5Supl2 p3467

Marvulo, M. F. V., Ferreira, F., Dias, R. A., Amaku, M., Groff, A. C. M., Gonçalves, V. S. P.,... Ferreira Neto, J. S.. (2009). Situação epidemiológica da brucelose bovina no estado do Rio Grande do Sul. Arquivo Brasileiro de Medicina Veterinária e Zootecnia, 61(Supl. 1), 93-102. doi: 10.15 90/S0102-09352009000700012

Minharro, S., Silva Mol, J. P., Dorneles, E. M. S., Pauletti, R. B., Neubauer, H, Melzer, F., Lage, A. P. (2013). Biotyping and genotyping (MLVA16) of Brucella abortus isolated from cattle in Brazil, 1977 to 2008. PLoS ONE, 8(12), e81152. doi: 10.1371/journal. pone.0081152
Ministério da Agricultura, Pecuária e Abastecimento - MAPA (2017). Instrução Normativa SDA No 10, de 3 de março de 2017. Recuperado de 7/10/2019 https:// www.gov.br/agricultura/pt-br/assuntos/ sanidade-animal-e-vegetal/saudeanimal/programas-de-saude-animal/ pncebt/controle-e-erradicacao-dabrucelose-e-tuberculose-pncebt

Ministério da Agricultura, Pecuária e Abastecimento-MAPA(2020).Diagnóstico situacional do PNCEBT. Recuperado de https://www.gov.br/agricultura/pt-br/ assuntos/sanidade-animal-e-vegetal/ saude-animal/programas-de-saudeanimal/pncebt/DSPNCEBT.pdf

Negreiros, R. L., Dias, R. A., Ferreira, F., Ferreira Neto, J. S., Gonçalves, V. S. P., Silva, M. C. P.,... Amaku, M. (2009). Situação epidemiológica da brucelose bovina no estado do Mato Grosso. Arquivo Brasileiro de Medicina Veterinária e Zootecnia, 61(Supl. 1), 56-65. doi: 10.1590/S010209352009000700008

Ogata, R. A., Gonçalves, V. S. P., Figueiredo, V. C. F., Lobo, J. R., Rodrigues, A. L., Amaku, M.,... Dias, R. A. (2009). Situação epidemiológica da brucelose bovina no estado do Tocantins. Arquivo Brasileiro de Medicina Veterinária e Zootecnia, 61(Supl. 1), 126-134, 2009. doi: 10.1590/ S0102-09352009000700016

Oliveira, L. F., Dorneles, E. M. S., Mota, A. L. A. A., Gonçalves, V. S. P., Ferreira Neto, J. S., Ferreira, F.,... Lage, A. P. (2016). Seroprevalence and risk factors for bovine brucellosis in the State of Minas Gerais, Brazil. Semina: Ciências Agrárias, 37(5), 3449-3446. doi: 10.5433/ 1679-0359.2016v37n5Supl2p3449 
Paulin, L. M., \& Ferreira Neto, J. S. (2003). O combate à brucelose bovina. Situação brasileira. Jaboticabal: Funep.

Paulin, L. M., \& Ferreira Neto, J. S. (2002). A experiência brasileira no combate à brucelose bovina. Arquivos do Instituto Biológico, 69(2), 105-112. Recuperado de http://www.biologico.agricultura.sp.gov. br/uploads/docs/arq/V69_2/paulin.pdf

Rocha, W. V., Gonçalves, V. S. P., Coelho, C. G. N. F. L., Brito, W. M. E. D., Dias, R. A., Delphino, M. K. V. C.,... Brito, L. A. B. (2009). Situação epidemiológica da brucelose bovina no estado de Goiás. Arquivo Brasileiro de Medicina Veterinária e Zootecnia, 61(Supl. 1), 27-34. doi: 10.1590/S010209352009000700005

Salman, M. D., \& Meyer, M. E. (1984). Epidemiology of bovine brucellosis in the Mexicali Valley, Mexico: literature review of disease-associated factors. American Journal of Veterinary Research, 45(8), 1557-1560. Recovered from https://euro pepmc.org/article/med/6476569

Secretaria da Agricultura, Pecuária e Aquicultura do Estado de Tocantins (2021). Pecuária. Recuperado de https:// seagro.to.gov.br/pecuaria/

Secretaria de Planejamento e Orçamento (2017). Indicadores socioeconômicos do estado do Tocantins. Recuperado de https://central3.to.gov.br/arquivo/414142/

Sikusawa, S., Amaku, M., Dias, R. A., Ferreira Neto, J. S., Martins, C., Gonçalves, V. S. P.,... Ferreira, F. (2009). Situação epidemiológica da brucelose bovina no estado de Santa Catarina. Arquivo Brasileiro de Medicina Veterinária e Zootecnia, 61(Supl. 1), 103-108. doi: 10. 1590/S0102-09352009000700013
Silva, N. S., Groff, A. C. M., Vidor, A. C. M., Grisi-Filho, J. H. H.., Heinemann, M. B., Dias, R. A.,... Ferreira Neto, J. S.. (2016). Epidemiological situation of bovine brucellosis after implementation of a vaccination program in Rio Grande do Sul State, Brazil. Semina: Ciências Agrárias, 37(5), 3519-3530. doi: 10.5433/ 1679-0359.2016v37n5Supl2p3519

Silva, V. G. S. O., Dias, R. A., Ferreira, F., Amaku, M., Costa, E. L. S., Lobo, J. R.,... Ferreira Neto, J. S. (2009). Situação epidemiológica da brucelose bovina no estado de Sergipe. Arquivo Brasileiro de Medicina Veterinária e Zootecnia, 61(Supl. 1), 109-117. doi: 10. 1590/S0102-09352009000700014

Souza, V. A. F., Ferreira Neto, J. S., Amaku, M., Dias, R. A., Telles, E. O., Grisi-Filho, J. H. H...... Ferreira, F. (2016). Mathematical modeling of bovine brucellosis control using the RB51. Semina: Ciências Agrárias, 37(5), 3767-3776. doi: 10.5433/ 1679-0359.2016v37n5Supl2p3767

Thoen, C. O., Enright, F., \& Cheville, N. F. (1993). Brucella. In C. L. Gyles, \& C. O. Thoen (Ed.). Pathogenesis of bacterial infections in animals (2nd ed., pp. 236-247). Ames: lowa State University Press.

Thrusfield, M. (2007). Veterinary epidemiology (3nd ed.). Oxford: Blackwell Science Ltd.

Villar, K. S., Amaku, M., Dias, R. A., Ferreira Neto, J. S., Benitez, F., Gonçalves, V. S. P.,... Ferreira, F. (2009). Situação epidemiológica da brucelose bovina no estado de Rondônia. Arquivo Brasileiro de Medicina Veterinária e Zootecnia, 61(Supl. 1), 85-92. doi: 10.1590/S010209352009000700011 
